18. Способы номинации в современном русском языке / Д.Н. Шмелев, А. Ф. Журавлев, О. П. Ермакова и др.; отв. ред. Д. Н. Шмелев. - М. : Наука, 1982. - 296 c.

19. Шеремета, Н. П. Південноволинсько-подільське діалектне порубіжжя (за матеріалами тваринницької лексики) : дис. ... канд. філол. наук : 10.02.01 / Шеремета Наталія Петрівна. - Кам’янець-Подільський, 2000. - 321 с.

20. Ястремська, Т. О. Структурно-семантична організація та географічна диференціація пастушої лексики гуцульського говору : автореф. дис. на здобуття наукового ступеня канд. філол. наук : спец. 10.02 .01 «Українська мова» / Т. О. Ястремська. - К., 2002. - 19 с.

Стаття надійшла 10.03.2016 року

УДК 811.161.2’38:821.161.2

Олександр Черевченко, Вікторія Черевченко

(Умань, Украӥна)

\title{
ЛІНГВОСТИЛІСТИЧНЕ МОДЕЛЮВАННЯ ПОЕТИЧНОГО ТЕКСТУ УКРАЇНСЬКОГО НЕОКЛАСИЦИЗМУ
}

Статтю присвячено дослідженню особливостей лінгвостилістичного моделювання поетичного тексту, виявленню функціонально-мовних закономірностей y поезї. У роботі визначено егоцентричні особливості поетичного мовлення, проаналізовано специфіку поетичного висловлювання. Лексична система характеризується використанням різних груп лексики як за походженням (народнорозмовна, старослов'янська, діалектна, просторічна, запозичена), так $i$ за тривалістю перебування та місием у мовній системі (архаїчна, індивідуальноавторська, історично та культурно маркована). Дослідження ідіостилів поетівнеокласиків дало можливість виявити універсальне та специфічне в поетичному мовленні як моделі комунікації.

Ключові слова: поетичний текст, мовна картина світу, поетичний дискурс, ідіостиль, образно-символічна паралель.

\footnotetext{
Черевченко А., Черевченко В. Лингвостилистическое моделирование поэтического текста украинского неоклассицизма.

Статья посвящена исследованию особенностей лингвостилистического моделирования поэтического текста, определению функиионально-языковых закономерностей в поэзии. В работе определень эгочентрические особенности поэтической речи, исследована специфика поэтического выражения. Лексическая система характеризуется использованием различных групп лексики по происхождению (разговорная, старославянская, диалектная, просторечная, заимствованная) и временем существования в языковой системе (архаическая, индивидуально-авторская, исторически и культурно маркированная). Исследование идиостилей поэтов-неоклассиков дало возможность определить универсальное и специфическое в поэтической речи как модели коммуникации.
} 
Ключевые слова: поэтический текст, языковая картина мира, поэтический дискурс, идиостиль, образно-символическая параллель.

Cherevchenko O., Cherevchenko V. The linguistic modeling of poetic text of Ukrainian neoclassicism.

The article is devoted to linguistic modeling of the communicative parameters of poetic text as well as revealing of linguistic functional laws of the text activity in poetry. The article studies egocentric peculiarities of poetic speech. It also determines parameters of the text addressee in poetry. It presents analyses of the distinguishing features of poetic expression. The lexical system is characterized by the use of lexical groups differing both in their origin (conversational, old Slavic, dialect, low colloquial, borrowed) and duration and place of their existence in the language system (archaic, individually author's, historically and culturally marked). The newest tendencies of developing modernist literature account for aesthetic usage of phonetic means. The research of communicative structure on the material of idiosyncrasy of Y. Klen's, M. Zerov, M. Drai-Khmara gave the opportunity to reveal universal and specific features in the poetic speech as a model of communication.

Keywords: poetic text, communicative structure, poetic discourse individual style image and symbolic parallel.

Сучасна лінгвостилістика постулює образну теорію поетичної мови як моделювальної системи, що характеризується певною пізнавальною потужністю та обов' язковою вмотивованістю мовних одиниць. Тенденція розглядати поетичний образ у взаємозв'язку 3 процесами мислення людини, пізнання й праці свідомості бере витоки з положень О. Потебні, який трактував образ як засіб мислення та пізнання. Це положення розвивається у працях М. Бахтіна, В. Виноградова, Г. Винокура, які зазначали, що поетичний образ несе інформацію про пізнання індивідом (автором) дійсності та уособлює розумовий зміст.

Створюючи образ на базі інформації, що отримується по сенсорних та моторних каналах, митець будує власну модель бачення світу в цілому та в окремих його явищах. При цьому в рамках старого значення через образне уподібнення здійснюється інтерпретація нового змісту. Слід зазначити, що в основі індивідуального світосприйняття лежать універсальні для усього соціуму поняття та уявлення, відображені у поетичному різновиді мовної творчості.

Поетична творчість київських неокласиків (М. Драй-Хмара, М. Зеров, Ю. Клен (Освальд Бургхардт), М. Рильський, П. Филипович), так званого «грона п’ятірного», $\epsilon$ частиною загальноукраїнського літературного процесу. Та прогалина, що утворилася внаслідок умовного заідеологізованого поділу нашого письменства на власне українське та емігрантське, стала причиною півстолітнього ігнорування та забуття творчого здобутку письменників-неокласиків. Сьогодні поетична спадщина митців, їі ідіостильові ознаки потребують детального наукового дослідження. 
Вітчизняні й зарубіжні вчені кваліфікують поетичну мову неокласиків як неординарне явище в історії української словесної творчості. За визначенням М. Неврлого, «здобутки світової класики, починаючи 3 античності i кінчаючи французькими парнасцями та німецькими експресіоністами, вони органічно поєднували з вітчизняною традицією. Своєю творчістю неокласики утворили самобутній i повнокровний поетичний стиль, пройнятий духом справжнього гуманізму» [11, с. 78]. У контексті сказаного, одним із актуальних завдань вважаємо визначення основних засад моделювання картини світу взагалі та з'ясування істотних ознак поетичної картини світу митця-неокласика.

Мета дослідження полягає в тому, щоб на основі лексикосемантичного та концептуального аналізу охарактеризувати стильові ознаки поетичної картини світу неокласиків.

Для досягнення поставленої мети слід розв' язати такі завдання:

- розкрити онтологічний та аксіологічний аспекти поетичної мовотворчості;

- визначити основні засади моделювання поетичної картини світу у творчості неокласиків;

- 3'ясувати головні ознаки ідейно-стильової парадигми київських неокласиків.

Дослідження останніх років зосереджують увагу на мовних засобах, які експлікують об' єктивну картину світу. 3 огляду на досвід площинного моделювання мовної картини світу, деякими вченими (Л. Вітгенштейном, В. Виноградовим, Ю. Карауловим, І. Ревзіним, Ю. Степановим, Н. Хомським та ін.) здійснено спробу об'ємного просторового моделювання мовної картини світу, особливість якого полягає у виявленні лексико-семантичних універсалій. Цікавою у цьому відношенні $\epsilon$ класифікація універсальних понять, запропонованих Р. Халлігом та В. фон Вартбургом. Це положення перегукується 3 твердженням про те, що «властивий мові спосіб концептуалізації дійсності частково універсальний, частково національно специфічний, тому носії різних мов можуть бачити світ дещо по-різному, крізь призму своїх мов» [1, с. 62]. Воно знайшло широке визнання серед дослідників.

На особливу увагу заслуговує антропо- та етноцентрична концепція лексичного значення, що належить відомій польській лінгвістці XX ст. А. Вежбицькій, яка розвиває ідеї М. Боас, В. фон Гумбольдта, О. Єсперсена, Е. Сепіра, Б. Уорфа. У цій концепції наголошується, що мова, по-перше, $є$ антропоцентричною, тобто призначеною для людини, $\mathrm{i}$, відповідно, мовна категоризація реалій зовнішнього світу теж зорієнтована на людину - така загальна властивість усіх мов. По-друге, кожна мова національно специфічна. При цьому вона відбиває не тільки особливості національної культури, а й своєрідність національного 
характеру ¥іi носіїв. Тому джерело «мовних розбіжностей» у концептуалізації світу слід шукати не тільки в особливостях природнокультурних умов буття, але й у своєрідності національних характерів [3, c. 263-282].

Кожний народ експлікує в мовні формули особливості свого світосприйняття. Він не тільки фотографує, інтерпретує світ засобами мовної символіки, а й створює свій ментальний портрет світу. У національній мові $\epsilon$ невичерпний арсенал мовних артефактів - образів, символів, знаків, які втілюють у собі результати пізнавальної діяльності всієї етнокультурної спільноти. Національна мова у свій неповторний спосіб перекодовує досвід колективно-історичної групи. Здійснюється цей процес через призму мовної особистості.

У лінгвістичних дослідженнях тривалий час зв'язок між культурною самобутністю, унікальністю етнічної спільноти і таким феноменом, як мовна картина світу, висвітлювався вкрай мало, а то й зовсім ігнорувався. Однак традиція, започаткована ще наприкінці XIX - на початку XX ст., виходила саме з розгляду двох вищеназваних проблем у їхньому тісному взаємозв'язку. Наприклад, особливості національного характеру розглядалися у рамках гумбольдтіанської теорії конститутивного характеру мови (О. Потебня, О. Веселовський, Д. ОвсяникоКуликовський). Якщо говоримо про національномовну особистість, то закономірно говорити про мовну картину світу як етнопсихолінгвістичне поняття. На взаємозв'язку мови, мислення й духу народу наполягав видатний німецький філософ і гуманіст, один із ідеологів «Бурі й натиску» Й.-Г. Гердер. Він зазначав, що мова віддзеркалює не лише особливості мислення, а й специфіку національного характеру: «У кожній мові відобразився розум і характер народу» [4, с. 239]; «Усяка мова - це посудина, в якій відливаються, зберігаються і передаються ідеї та уявлення народу» [4, с. 297]. Кожний народ бачить світ по-своєму i відображає це бачення в певних проявах, зокрема мовотворчості. Про світоглядний зміст кожної національної мови писав ще В. фон Гумбольдт: «Різні мови - це не різні позначення того самого предмета, а різні бачення його» $[5$, с. 9].

Проблему співвідношення національної мови i національного світобачення обгрунтовували неогумбольдтіанці. Представник етнолінгвістичної школи Л. Вайсгербер («Про сили німецької мови», 1945-1955) доводив, що кожна мова має свій, тільки іій властивий, світогляд. У сучасному мовознавстві дослідники вирізняють етнічні мовні картини світу, у які «занурені» всі члени суспільства [10, с. 87].

Етнокультура, таким чином, виступає найважливішим показником національної свідомості, створює специфічне «етнічне поле» [10, с. 93], що формує ментальність того чи іншого народу. Це положення базується 
на гіпотезі лінгвістичної відносності Е. Сепіра та Б. Уорфа, які стверджують, що структура мови впливає на спосіб мислення і поведінки людини. Через це носії мови схильні сприймати дійсність по-різному, залежно від семантичних категорій, закладених у мовному коді. У такий спосіб відбувається рецепція сприймання і розуміння, що створює універсальну філософську систему, за якою живе та чи інша етноспільнота і відповідно користується той чи інший мовець.

У творчості будь-якого поета чільне місце посідають елементи, що характеризують його історичну епоху, іiі світоглядні орієнтири. У своїй сукупності вони створюють своєрідну модель володіння світом. Література на зламі XIX-XX ст., як і культура в цілому, представлена багатоманітністю напрямів, течій, форм. Це був час заперечення усталених норм і традицій, руйнації старих моральних i художніх цінностей, пошуків нових мистецьких форм. «Від початку століття в українській поезії утверджується новий тип митця 3 модерним комплексом світобачення та своєрідним мисленням. Цей митець прийшов на зміну тим, хто мав народницькі погляди на мистецтво, коли воно ототожнювалося 3 самим життям і зводилося до утилітарного призначення» [13, с. 28].

Новітні тенденції модерної поезії визначили естетичні особливості художнього дискурсу, у якому «відбувається руйнування комунікативної природи, останній не відсилає до реальності, не називає об'єкти, не забезпечує адекватності мови і значення. Він передусім стилізує, замикає на собі» [6, с. 30, 144]. Так, у маніфесті дадаїстів зазначено: «Я не хочу слів, які винайдені іншими. Я просто виробляю звуки. Спливають слова, плечі слів, ноги, руки, долоні слів» [2, с. 316-317], тобто культивувалося своєрідне заперечення соціальної, а відповідно мовної, свідомості. Представники «Української хати», на відміну від модерністів, акцентували свою увагу на потенційних можливостях семантичних компонентів тексту усієї української культури і прагнули розширити суспільні функції української мови.

Разом 3 тим однією з характерних рис української літератури 20-х рр. стала висока частотність звернення до «вічних» образів світової та вітчизняної літератури й культури, що зумовлювалося глобальними історичними зрушеннями (революцією, війною, різкими змінами суспільно-політичного життя тощо), які завжди якісно впливають на процес розвитку духовного життя нації. Це був своєрідний сплеск художньо-мистецького інтересу до минувшини - героїв античних міфів, сюжетної багатоплановості Біблії, визначення ролі тих чи тих історичних осіб або героїв літературних творів попередніх епох. У його картинах митці прагнули віднайти певні ідеальні орієнтири як протиставлення жорстокій сучасності, що не давала надії на світле майбуття. 
Наведені приклади торкаються лише окремих літературних маніфестацій (на той час в українській літературі їх було набагато більше), однак дають уявлення про новий стан культури початку XX ст., який характеризувала тенденція до синтезу найрізноманітніших, часто взаємовиключних напрямів розвитку.

20-ті роки XX ст. позначені напруженими ідейно-художніми i стильовими пошуками. $\mathrm{Y}$ цей час розбудовується національний український стиль і зароджується основа нової псевдоестетики, яка згодом визначиться як естетика соціалістичного реалізму. Ідеологічні табу, що накладалися на літературу, породжували ії заангажованість. Як зазначає Ю. Ковалів, «неприємно вражали чвари між літературними угрупованнями, а особливо атаки на попутників» 3 боку адептів вульгарно тлумаченого мистецтва на «пролетарській платформі» (Київська платформа «Гарту» на чолі 3 сумнозвісним критиком Б. Коваленком), естетична безпорадність та егалітарний «масовізм» «Плуга» (С. Щупак), їхне нігілістичне ставлення до світової та національної класики, примітивні уявлення про літературний талант» [9, с. 7]. Одним із необхідних завдань пролетарська література проголошувала, наприклад, створення індустріальної динамічної культури (В. Поліщук «Завдання доби»).

Так чи інакше, історична специфіка різноманітних моделей поетичної мови зумовлювалася насамперед тими правилами, якими керувався письменник. На кожному етапі художньої еволюції персональні варіанти смислових трансформацій об'єднуються в міжіндивідуальні системи, 3 часткових моделей і виростає загальна картина поетичної мови конкретної епохи. Кожна поетична маніфестація (залежно від естетичної програми) виробляла свою специфічну модель поетичної мови, яка змушувала митців дотримуватися відповідних (певному угрупованню) норм слововживання, тематичної визначеності.

Філософсько-естетичним тлом українського неокласицизму стала концепція софійності. Головна іiі ідея - утвердження мудрості і краси світобудови, творення світу як розумного мистецтва. Особливістю художнього світосприйняття неокласиків, яке концентрується навколо ідеї краси, виступає традиційний поетичний антропоцентризм: «Краса ide, гаптує золотом / Ясні, глибокі небеса, - / А ми затоптуєм болотом / Все те, щуо в нас самих - краса» [12, с. 140]. Духовний світ людини осягається митцями у філософській єдності особистості й довкілля, розглядається у площині вічних проблем - добра і зла, життя і смерті, людини й часу, буття й культури.

Наснажені ідеєю цілісної гармонії («калокагатії»), неокласики намагаються привести будь-який новий стан речей у відповідність із моделлю ідеальної рівноваги Всесвіту. Через використання лексем слово, 
смак, калагатія (поезія М. Зерова «Класики») актуалізуються семантичні ознаки класичної поезії: «ваше слово, смак, калагатія. / Для нас лише порив, недосяжна мрія / Та гострої розлуки гострий біль» [8, с. 65]. Негативне емоційно-експресивне маркування словосполучень недосяжна мрія, гостра розлука, гострий біль стає ознакою занепаду не тільки літературно-художніх надбань людства, а й засобом критики тогочасних суспільно-політичних порядків.

Аналіз поетичного доробку неокласиків доводить, що вони одностайні у баченні античних авторів (Гомера, Овідія, Вергілія, Горація, Катулла та ін.) як ідеальних митців: «Mи - неокласики. Завзято / милуємось на древній світ / $i$ все не хочемо вмирати: / Гомер, Горацій, Геракліт» [8, с. 107]. Разом 3 тим використання цих образів слугує своєрідним натяком на тогочасну дійсність (20-30-х рр. ХХ ст.). Так, у поезії «Аристарх» М. Зеров створив яскраву алюзію на заідеологізовану пролетарську поезію, де тимчасовий поетичний злет («Сплітали для владик вінки нікчемних од») протиставлено високому покликанню митця: служити вічності, бути духовним пастирем людства: «Де мудрий Аристарх, філолог і естет, / для нових поколінь, на глум зухвалій моді, / заглиблювався в текст Гомерових рапсодій» [8, с. 82].

Поряд 3 античним образно-сюжетним матеріалом у формуванні культурологічного шару неокласичного дискурсу беруть участь біблійні образи i мотиви, які допомагають митцям осмислювати тогочасну ситуацію. Поетично відтворена картина розп’яття Ісуса Христа набуває масштабів космічної катастрофи. Син Божий існує поряд із символом хреста, в його образі домінує людська природа, через його земне існування можна осягнути всю трагічність історії. Інтерпретація біблійних сюжетів («Чистий четвер», «Страсна п’ятниця» М. Зерова) дозволяє торкнутися рис сучасності: «I темний ряд євангельських історій / звучить як низка тонких алегорій / про наші підлі i скупі часи» [8, с. 64], концептуально розкрити принципи трансформації біблійних образів у неокласичному поетичному доробку. Історична трагедія України символічно передається через образи Пророка й Лазаря (вірш П. Филиповича «На поталу камінним кригам»): «Поруч серце чуже холоне, / умира, не може любить. / I на всій безмежній крайні / ні один ще Лазар не встав» [14, с. 51].

Створюючи глибоко філософські поетичні твори, неокласики звертаються до класичних поетичних форм - сонета, рондо, ідилії, терцини, олександрійського вірша. Зумовлено це не тільки естетичними засадами, а й раціоналізмом світосприйняття. «Красу, гармонію світу зазначає В. Зварич, - поети прагнули відтворити у письмі через кристалізовані досвідом художні форми, які зберігають пам'ять культур і демонструють потужний потенціал самооновлення» [7, с. 27]. У цьому 
аспекті неокласики продовжують традиції Т. Шевченка, І. Франка, Лесі Українки, В. Самійленка.

Слід зазначити, що неокласики перебували під впливом тенденції до ускладнення поетичної думки, яка передбачала укладання ліричної збірки за принципом замкненої цілісності, об'єднаної спільною концепцією. Так чи інакше, окрема поезія стає ланкою єдиного задуму, єдиної розгалуженої концепції, єдиного внутрішнього сюжету, багатшою й змістовнішою через свої зв'язки із сусідніми. Принципи циклізації вияскравлюють неокласичне розуміння дійсності, конкретизують їхній естетичний ідеал, у межах лірики відтворюваний лише у складній системі поетики (фонетичних, лексичних, словотвірних, морфологічних, синтаксичних засобах), що об'єктивно зумовлено новим синтетичним станом культури початку ХХ ст.

Культурно-мистецькі погляди неокласиків вирізнялися глибоким естетизмом. Орієнтація письменників на античність, творчість парнасців, золотий і срібний вік російської поезї, символізм і акмеїзм зумовила особливу увагу до форми, поетичної техніки, культури поетичного слова. Усвідомлення культурного (естетичного, літературного, мовного) відставання України, спричиненого ㄲï довготривалим колоніальним становищем, директивними утисками щодо національної мови й літератури, а звідси порушенням природної еволюції розвитку, особливо стильового, спонукало митців виробити чітку програму літературної творчості. Ними було сформульовано й реалізовано основні положення ідейно-естетичної платформи, які полягали у засвоєнні європейської та національної культурної спадщини - головної передумови подальшого розвитку національної літератури як шляху подолання мистецької аморфності, інтенсифікації загального мовного розвитку та поетичного стилю, збагаченого новими словесно-художніми засобами. Незважаючи на належність авторів до одного літературного угруповання, мовна картина світу кожного з них позначена індивідуальними особливостями. Через кристалізовані досвідом художні форми, які зберігають пам'ять культур, поети прагнули відтворити красу, гармонію світу.

У контекстній семантиці неокласичних образів виразно позначився синтез фольклорно-міфологічного мислення і традиції поетичної мови. Концептуальний характер у мовотворчості митців виявляють образносимволічні моделі життя - вода, життя - земля, життя - сонце, життя - душа, які репрезентують особливості етносвідомості, значно розширюючи їх за рахунок історико-літературних алюзій чи ремінісценцій, темпоральних, звукових, зорових ознак. Ці моделі формують міфопоетичні категорії неокласичної естетичної системи. Семантика аналізованих мовних одиниць пов'язана також із системою асоціативних комплексів, що постають на контекстах української 
етнокультури. Це зумовлює нашарування екстралінгвальних національнокультурних компонентів значення слів-образів. Активне використання міфологічних кодів у новій семантичній ситуації відображає авторське бачення суперечностей часу, зберігає онтологічний досвід людського буття.

\section{СПИСОК ВИКОРИСТАНОЇ ЛТТРАТУРИ}

1. Апресян, Ю.Д. Интегральное описание языка и толковый словарь / Ю. Д. Апресян // Вопросы языкознания. - 1986. - № 2. - С. 57-70.

2. Балль, Х. Манифест к первому вечеру дадаистов в Цюрихе / Х. Балль // Называть вещи своими именами: Программные выступления мастеров западноевропейской литературы XX века / сост., предисл., общ. ред. Л. Г. Андреева. - М. : Прогресс, 1986. - С. 316-317.

3. Вежбицкая, А. Семантические универсалии и описание языков / А. Вежбицкая ; пер. с англ. А. Д. Шмелёва ; под ред. Т. В. Булыгиной. - М. : Языки русской культуры, 1999. - I-XII, 780 с.

4. Гердер, И. Г. Идеи к философии истории человечества / И. Г. Гердер. - М. : Наука, 1977. - 349 с.

5. Гумбольдт, В. Язык и философия культуры / В. Гумбольдт ; пер. с нем. - М. : Прогресс, 1985. - 451 с.

6. Гундорова, Т. Проявлення Слова. Дискурсія раннього українського модернізму. Постмодерна інтерпретація / Т. Гундорова. - Львів, 1997. - 237 с.

7. Зварич, В. З. Стилетворчі функції традиційних образів у поезії неокласиків : дис. на здобуття наукового ступеня канд. філол. наук : 10.01.06 / Зварич Василь Захарович. - Дрогобич, 2002. - 175 с.

8. Зеров, М. К. Твори : у 2-х томах. Т. 1: Поезії. Переклади / М. К. Зеров. - К. : Дніпро, 1990. - 842 с.

9. Ковалів, Ю. І. Українська поезія першої пол. ХХ ст. / Ю. І. Ковалів. - К. : Перше вересня, 2000. - 39 с.

10. Космеда, Т. А. Аксіологічні аспекти прагмалінгвістики / Т. А. Космеда. Львів : ЛНУ ім. Івана Франка, 2000. - 340 с.

11.Неврлий, М. Українська радянська поезія 20-х років. Мікропортрети в художніх стилях і напрямах / М. Неврлий. - К. : Вища школа, 1991. - 269 с.

12. Рильський, М. Т. Зібрання творів у 20-ти томах / М. Т. Рильський. - Т. 1. - К. : Наук. думка, 1983. - 534 с.

13. Ставицька, Л. О. Естетика слова в українській поезії 10-30рp. ХХ ст. / Л. О. Ставицька. - К. : Правда Ярославичів, 2000. - 156 с.

14. Филипович, П. Поезії / П. Филипович. - К. : Рад. письменник, 1989. - 193 с. 